\title{
HYPOTHESIS
}

\section{The calcium-sensing receptor and insulin secretion: a role outside systemic control 15 years on}

\author{
M N Hodgkin, C E Hills ${ }^{1}$ and $\mathbf{P}$ E Squires \\ Department of Biological Sciences, University of Warwick, Coventry CV4 7AL, UK \\ ${ }^{1}$ Department of Infection, Immunity and Inflammation, Leicester School of Medicine, University of Leicester, PO Box 138, Leicester LE1 7RH, UK \\ (Correspondence should be addressed to P E Squires; Email: p.e.squires@warwick.ac.uk)
}

\begin{abstract}
In the 15 years since the identification and characterisation of the extracellular calcium-sensing receptor $(\mathrm{CaR})$, it has become increasingly apparent that this cationic binding receptor is found in many tissues, not associated with the control of plasma calcium. One of these tissues is the pancreatic islet where insulin secretion provides the basis of energy regulation. It seems inherently unlikely that the islet responds to alterations in systemic calcium and a more plausible and intriguing possibility is that the $\mathrm{CaR}$ mediates
\end{abstract}

cell-to-cell communication through local increases in the concentration of extracellular $\mathrm{Ca}^{2+}$, co-released with insulin. This short article explores this possibility and suggests that this novel mechanism of cell communication, along with direct coupling via gap junctions and other local paracrine regulators helps explain why the glucose responsiveness of the intact islet is greater than the sum of the composite parts in isolation.

Journal of Endocrinology (2008) 199, 1-4

\section{Introduction}

It has been 15 years since the original cloning and characterisation of the extracellular calcium-sensing receptor (CaR; Brown et al. 1993). Since then more than 1000 articles have been published chronicling the role of this $G$ proteincoupled receptor in the physiology and pathophysiology of systemic calcium regulation (extensively reviewed in Brown 2007). However, over the last decade and a half it has become apparent that the ability of cells to detect local changes in free calcium ion concentration is not restricted to tissues involved in $\mathrm{Ca}^{2+}$ homeostasis. The CaR has been detected in an ever increasing range of tissue types, including oesophageal (Justinich et al. 2008) and colonic epithelia (Cheng et al. 2004), the cardiovascular system (reviewed in Smajilovic \& Tfelt-Hansen 2007), hypothalamic neurons (Vizard et al. 2008), pancreatic ducts (Racz et al. 2002) and pancreatic $\alpha$ - and $\beta$-cells (Rasschaert \& Malaisse 1999, Squires et al. 2000, Gray et al. 2006).

The functional significance of the $\mathrm{CaR}$ in tissue not involved in regulating plasma $\mathrm{Ca}^{2+}$ is not fully understood. In the exocrine pancreas, it has been suggested that the $\mathrm{CaR}$ monitors extracellular $\mathrm{Ca}^{2+}$ in pancreatic juice to limit the risk of calcium carbonate stone formation (Bruce et al. 1999) and in gastrinsecreting cells of the human antrum the $\mathrm{CaR}$ may detect dietary $\mathrm{Ca}^{2+}$ (Ray et al. 1997, Buchan et al. 2001). However, a more global explanation for the role of the $\mathrm{CaR}$ in these disparate tissues could be in its ability to detect local fluctuations in $\mathrm{Ca}^{2+}$, mediating cell-to-cell communication and coupling function. Cells communicate locally via gap junctions that physically connect adjacent cells and permit the free flow of ions and small molecules (Hills et al. 2006), or through the release of local paracrine messengers (Squires et al. 2002). Recent evidence, from our work on pancreatic $\beta$-cells, suggests an important function for the $\mathrm{CaR}$ in mediating cell-to-cell communication within islets to coordinate insulin secretory responses (Jones et al. 2007). Local changes in the concentration of extracellular $\mathrm{Ca}^{2+}$ can occur as result of changes in $\mathrm{Ca}^{2+}$-influx/efflux pathways across the plasma membrane (Green et al. 2007). Additionally, secretory granules contain high concentrations of calcium that is released upon exocytosis (Belan et al. 1998). As the volume of space between cells is often small, large changes in $\mathrm{Ca}^{2+}$ concentration can occur in the microenvironment immediately surrounding cells (Perez-Armendariz \& Atwater 1986). These local extracellular 'hot-spots' of calcium are sufficient to activate the $\mathrm{CaR}$ on neighbouring cells and facilitate cellular co-operation.

\section{CaR: cell-to-cell communication and the pancreatic islet}

Several theories have been proposed to explain the synchronous and cooperative activity of islets when compared with 
non-cooperative events in isolated individual $\beta$-cells including direct communication via gap junctions (Moreno et al. 2005, Rogers et al. 2007), the presence of other endocrine cells (Ishihara et al. 2003), as well as the existence of extracellular diffusible mediators (Squires et al. 2002, Hellman et al. 2004). The possibility that local changes in extracellular $\mathrm{Ca}^{2+}$, resulting from the efflux of mobilised $\mathrm{Ca}^{2+}$, in one cell are sufficient to activate the $\mathrm{CaR}$ on an adjacent cell was elegantly demonstrated in a HEK293 model system (Hofer et al. 2000). These studies suggested that the extrusion of $\mathrm{Ca}^{2+}$ from stimulated cells, recruited neighbouring cells, allowing amplification and integration of a tissue-wide response (reviewed in Hofer et al. 2004). In the pancreas, we have long argued that close cell-to-cell contact improves the functional responsiveness of cells and augments insulin secretion (Hauge-Evans et al. 1999). Activation of the CaR using receptor-specific calcimimetics (reviewed in Trivedi et al. 2008) enhances insulin secretion from human islets (Gray et al. 2006) and provides an obvious link by which glucose-evoked release of calcium-rich secretory granules feeds forward to synchronise secretion and perpetuate the whole islet response. The proposed model of this $\mathrm{CaR}$-mediated propagation of signals across the islet is illustrated in the schematic below. Here, glucose-evoked changes in insulin secretion in one cell can stimulate insulin secretion from neighbouring cells expressing the $\mathrm{CaR}$, through co-release of divalent cations, ultimately improving overall secretory function (Fig. 1).
It is unusual for receptor-mediated stimuli to initiate insulin release in the absence of stimulatory glucose concentrations. However, calcimimetic activation of the $\mathrm{CaR}$ in human and rodent $\beta$-cells transiently increases insulin secretion, without the need for an associated increase in nutrient stimulation (Gray et al. 2006), stressing the potential importance of the $\mathrm{CaR}$ to islet function. It is therefore surprising that activating mutations of the $\mathrm{CaR}$ as seen in autosomal-dominant hypocalcaemia (extensively reviewed in Egbuna \& Brown 2008) cause hypocalcaemia of varying severity without hypoglycaemia as expected from an increase in insulin secretion under the current model. This discrepancy could be explained by the fact that hypocalcaemia has been shown to reduce insulin secretion (Schlumbohm \& Harmeyer 2002), perhaps through a reduced drive for $\mathrm{Ca}^{2+}$ entry following glucose-stimulated closure of the ATPsensitive potassium channels on the $\beta$-cells. Certainly, if $\mathrm{CaR}$ function is increased in pancreatic $\beta$-cells from a background of eucalcemia there is an increase in insulin secretion (Gray et al. 2006), an effect that may form the basis of the intra-arterial calcium stimulation test for the detection of insulinomas (Kato et al. 1997, Won et al. 2003). The loss of $\mathrm{CaR}$ function may partially explain increased prevalence of coincident diabetes in patients presenting with primary hyperparathyroidism, where the loss of $\mathrm{CaR}$ function in the parathyroid increases parathyroid hormone (PTH) secretion (reviewed in Taylor \& Khaleeli 2001).

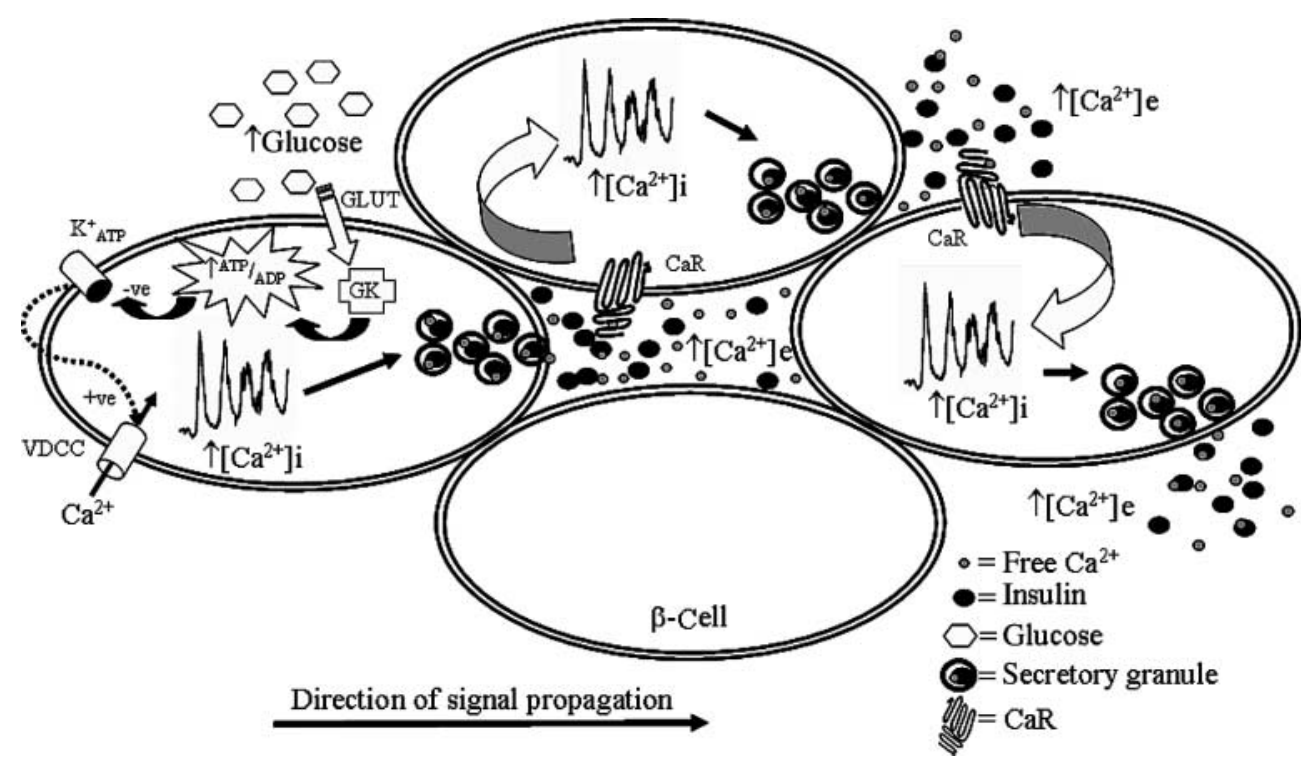

Figure 1 CaR-mediated cell-to-cell communication within pancreatic islets: glucose metabolism within pancreatic $\beta$-cells is limited by the low-affinity glucokinase (GK). The resultant rise in ATP/ADP ratio closes the ATP-sensitive potassium channels $\left(\mathrm{K}_{\text {ATP }}^{+}\right.$), depolarising the cell membrane and opening voltage-dependent $\mathrm{Ca}^{2+}$ channels (VDCC). Calcium enters the cell down a concentration gradient and stimulates insulin secretion $(\bullet)$. Divalent cations, including free $\mathrm{Ca}^{2+}\left({ }^{\circ}\right)$, are co-released with insulin, increasing the local concentration of extracellular calcium $\left(\uparrow\left[\mathrm{Ca}^{2+}\right]_{\mathrm{e}}\right)$ in the intra-islet space. These changes act in a paracrine fashion that is detected by the extracellular $\mathrm{Ca}^{2+}$-sensing receptor (CaR) on adjacent cells. CaR mediated increases in $\left[\mathrm{Ca}^{2+}\right]_{i}$, propagate the signal across the islet, thus co-ordinating activity and enhancing glucoseinduced insulin secretion. 


\section{CaR: a role in cell adhesion and proliferation in the islet}

The biosynthetic and secretory function of the islet depends largely on the architecture of the islet, itself dictated by specialised cell adhesion molecules such as the cell surface adhesion protein epithelial (E)-cadherin (ECAD) and $\beta$-catenin (reviewed in D'Souza-Schorey 2005). The colocalisation of adherens junction proteins to secretory granules (Hodgkin et al. 2007) suggests that the adherens junction may play a novel role in $\beta$-cell function, both in terms of $\beta$-cell proliferation (Carvell et al. 2007) and insulin secretion (Hodgkin et al. 2007, Rogers et al. 2007). Neutralising ECAD-mediated cell adhesion decreases glucose-evoked synchronicity in $\mathrm{Ca}^{2+}$ signals between adjacent cells within islets (Rogers et al. 2007) and evidence from human epidermal keratinocytes suggests that inactivation of the CaR suppresses the assembly of the ECAD-cateninphosphotidylinositol3-kinase (PI3K) complex (Tu et al. 2008). These data provide compelling evidence that the CaR influences multiple functions that ultimately regulate synchronicity of $\mathrm{Ca}^{2+}$ activity between $\beta$-cells within the islet and thus dramatically impinge on insulin secretion.

\section{Conclusion}

Calcium receptor-mediated cell-to-cell communication permits local changes in co-released $\mathrm{Ca}^{2+}$ to synchronise whole islet responses to secretagogues. It seems likely that the local paracrine function of extracellular $\mathrm{Ca}^{2+}$ acts in unison with other better characterised mechanisms for cellular coupling, to ensure appropriate glucose responsiveness. Calcimimetic compounds that activate the CaR and block PTH secretion have been developed to treat hyperparathyroidism, while calcilytic compounds potentially provide an anabolic therapy for osteoporosis (reviewed in Nemeth 2004). However, the expression of a functional $\mathrm{CaR}$ within human pancreatic islets suggests that these therapies may have wider implications for tissues outside the normal targets for control of systemic calcium, and these possible contraindications need to be fully explored. This short article demonstrates the importance of the $\mathrm{CaR}$ in orchestrating a synchronised whole islet response to improve secretory function.

\section{Declaration of interest}

The authors declare that there is no conflict of interest that could be perceived as prejudicing the impartiality of the research reported.

\section{Funding}

This work did not receive any specific grant from any funding agency in the public, commercial or not-for-profit sector.

\section{References}

Belan P, Gardner J, Gerasimenko O, Gerasimenko J, Mills CL, Petersen OH \& Tepikin AV 1998 Isoproterenol evokes extracellular $\mathrm{Ca}^{2+}$ spikes due to secretory events in salivary gland cells. Journal of Biological Chemistry 273 4106-4111.

Brown EM 2007 The calcium-sensing receptor: physiology, pathophysiology and CaR-based therapeutics. Sub-Cellular Biochemistry 45 139-167.

Brown EM, Gamba G, Riccardi D, Lombardi M, Butters R, Kifor O, Sun A, Hedlger MA, Lytton J \& Hebert SC 1993 Cloning and characterization of an extracellular $\mathrm{Ca}^{2+}$-sensing receptor from bovine parathyroid. Nature $366575-580$.

Bruce JIE, Yang X, Ferguson CJ, Elliot AC, Steward MC, Maynard-Case R \& Riccardi D 1999 Molecular and functional identification of a $\mathrm{Ca}^{2+}$ (polyvalent cation)-sensing receptor in rat pancreas. Journal of Biological Chemistry 274 20561-20568.

Buchan AMJ, Squires PE, Ring M \& Meloche MR 2001 Mechanism of action of the calcium-sensing receptor in human antral gastin cells. Gastroenterology 120 1128-1139.

Carvell MJ, Marsh PJ, Persaud SJ \& Jones PM 2007 E-cadherin interactions regulate $\beta$-cell proliferation in islet-like structures. Cellular Physiology and Biochemistry 20 617-626.

Cheng SX, Giebel JP \& Hebert SC 2004 Extracellular polyamines regulate fluid secretion in rat colonic crypts via the extracellular calcium-sensing receptor. Gastroenterology 126 148-158.

D'Souza-Schorey C 2005 Disassembling adherens junctions: breaking up is hard to do. Trends in Cell Biology 15 19-26.

Egbuna OI \& Brown EM 2008 Hypercalcaemia and hypocalcaemia conditions due to calcium-sensing receptor mutations. Best Practice and Research. Clinical Rheumatology 22 129-148.

Gray E, Muller D, Squires PE, Asare-Anane H, Huang G-C, Amiel S, Persaud SJ \& Jones PM 2006 Activation of the extracellular calcium-sensing receptor initiates insulin secretion from human islets of Langerhans: involvement of protein kinases. Journal of Endocrinology 190 703-710.

Green AK, Stratton RC, Squires PE \& Simpson AWM 2007 Atrial natriuretic peptide attenuates elevations in $\mathrm{Ca}^{2+}$ and protects hepatocytes by stimulating net plasma membrane $\mathrm{Ca}^{2+}$ efflux. Journal of Biological Chemistry 282 34542-34554.

Hauge-Evans AC, Squires PE, Persaud SJ \& Jones PM 1999 Pancreatic $\beta$-cellto- $\beta$-cell interactions are required for integrated responses to nutrient stimuli: enhanced $\mathrm{Ca}^{2+}$ and insulin secretory responses of MIN6 pseudoislets. Diabetes 48 1402-1408.

Hellman B, Dansk H \& Grapengiesser E 2004 Pancreatic $\beta$-cells communicate via intermittent release of ATP. American Journal of Physiology 286 E759-E765.

Hills CE, Bland R, Wheelans DC, Bennett J, Ronco PM \& Squires PE 2006 Glucose-evoked alterations in connexin 43-mediated cell-to-cell communication in human collecting duct: a possible role in diabetic nephropathy. American Journal of Physiology 291 F1045-F1051.

Hodgkin MN, Rogers GJ \& Squires PE 2007 Co-localization between $\beta$-catenin and insulin suggests a novel role for the adherens junction in $\beta$-cell function. Pancreas 34 170-171.

Hofer AM, Curci S, Doble MA, Brown EM \& Soybel DI 2000 Intercellular communication medicated by the extracellular cacium-sensing receptor. Nature Cell Biology 2 392-398.

Hofer AM, Gerbino A, Caroppo R \& Curci S 2004 The extracellular calcium-sensing receptor and cell-cell signalling in epithelia. Cell Calcium 35 297-306.

Ishihara H, Maechler P, Gjinovci A, Herrera P-L \& Wollheim CB 2003 Islet $\beta$-cell secretion determines glucagons release from neighbouring $\alpha$-cells. Nature Cell Biology 5 300-335.

Jones PM, Kitsou-Mylona I, Gray E, Squires PE \& Persaud SJ 2007 Expression and function of the extracellular calcium-sensing receptor in pancreatic $\beta$-cells. Archives of Physiology and Biochemistry 113 98-103.

Justinich CJ, Mak N, Pacheco I, Mulder D, Wells RW, Blennerhassett MG \& MacLeod RJ 2008 The extracellular calcium-sensing receptor (CaSR) on human esophagus and evidence of expression of the CaSR on the esophageal epithelial cell line (HET-1A). American Journal of Physiology 294 G120-G129. 
Kato M, Doi R, Imamura M, Furutani M, Hosotani R \& Shimada Y 1997 Calcium-evoked insulin release from insulinoma cells is mediated via calcium-sensing receptor. Surgery 122 1203-1211.

Moreno AP, Berthould V, Perez-Palacios G \& Perez-Armendariz EM 2005 Biophysical evidence that connexin-36 forms functional gap junction channels between pancreatic mouse $\beta$-cells. American Journal of Physiology 288 E948-E956.

Nemeth EF 2004 Calcimimetic and calcilytic drugs: just for parathyroid cells? Cell Calcium 35 283-289.

Perez-Armendariz E \& Atwater I 1986 Glucose-evoked changes in $\left[\mathrm{K}^{+}\right]$and $\left[\mathrm{Ca}^{2+}\right]$ in the intercellular spaces of the mouse islet of Langerhans. Advances in Experimental Medicine and Biology 211 31-51.

Racz GZ, Kittel A, Riccardi D, Case RM, Elliot AC \& Varga G 2002 Extracellular calcium sensing receptor in human pancreatic cells. Gut 51 705-711.

Rasschaert J \& Malaisse WJ 1999 Expression of the calcium-sensing receptor in pancreatic islet $\beta$-cells. Biochemical and Biophysical Research Communications 264 615-618.

Ray JM, Squires PE, Curtis SB, Meloche MR \& Buchan AMJ 1997

Expression of the calcium-sensing receptor on human antral gastrin cells in culture. Journal of Clinical Investigation 99 2328-2333.

Rogers GJ, Hodgkin MN \& Squires PE 2007 E-cadherin and cell adhesion: a role in architecture and function in the pancreatic islet. Cellular Physiology and Biochemistry 20 987-994.

Schlumbohm C \& Harmeyer J 2002 Hypocalcemia reduces insulin turnover but not insulin-mediated glucose metabolism in piglets. Acta Diabetologica 39 191-202.

Smajilovic S \& Tfelt-Hansen J 2007 Calcium acts as a first messenger through the calcium-sensing receptor in the cardiovascular system. Cardiovascular Research 75 457-467.
Squires PE, Harris TE, Persaud SJ, Curtis SB, Buchan AMJ \& Jones PM 2000 The extracellular calcium-sensing receptor on human $\beta$-cells negatively modulates insulin secretion. Diabetes 49 409-417.

Squires PE, Persaud SJ, Hauge-Evans AC, Gray E, Ratcliff H \& Jones PM $2002 \mathrm{Co}$-ordinated $\mathrm{Ca}^{2+}$-signalling within pancreatic islets: does $\beta$-cell entrainment require a secreted messenger. Cell Calcium 31 209-219.

Taylor WH \& Khaleeli AA 2001 Coincident diabetes mellitus and primary hyperparathyroidism. Diabetes/Metabolism Research and Reviews 17 175-180.

Trivedi R, Mithal A \& Chattopadhyay N 2008 Recent updates on the calcium-sensing receptor as a drug target. Current Medicinal Chemistry 15 178-186.

Tu C-L, Chang W, Xie Z \& Bikle DD 2008 Inactivation of the calcium sensing receptor inhibits E-cadherin-mediated cell-cell adhesion and calcium-induced differentiation in human epidermal keratinocytes. Journal of Biological Chemistry 283 3519-3528.

Vizard TN, O'Keeffe GW, Gutierrez H, Kos CH, Riccardi D \& Davies AM 2008 Regulation of axonal and dendritic growth by the extracellular calcium-sensing receptor. Nature Neuroscience 11 285-291.

Won JGS, Tseng H-S, Yang A-H, Yang K-T, Jap T-S, Kwok C-F, Lee CH \& Lin H-D 2003 Intra-arterial calcium stimulation test for detection of insulinomas: detection rate, responses of pancreatic peptides, and its relationship to differentiation of tumour cells. Metabolism 52 1320-1329.

\section{Received in final form 12 June 2008}

Accepted 23 June 2008

Made available online as an Accepted Preprint 24 June 2008 